\title{
Dye-Sensitized Solar Cell performance measurement analysis using Arduino Board
}

\author{
Hariyanto Hariyanto*, Muhammad Rusdi $^{2}$, Daniel Parenden ${ }^{1}$, Cipto Cipto ${ }^{1}$, and Klemens A. Rahangmetan ${ }^{1}$ \\ ${ }^{1}$ Department of Mechanical Engineering, Faculty of Engineering, Universitas Musamus, Merauke 99600, Indonesia \\ ${ }^{2}$ Department of Electrical Engineering, Faculty of Engineering, Universitas Musamus, Merauke 99600, Indonesia
}

\begin{abstract}
Dye-Sensitized Solar Cell is a type of solar cell that is being developed by researchers around the world. The purpose of this research is to analyse the performance measurement of DSSC using Arduino Nano. The DSSC used as the sample is the result of fabrication with the pipette method and red fruit colouring material. The data measurement method is carried out in real-time using Arduino nano devices and sensors that have been assembled. The measurement results are presented in the form of graphs and tables, while the parameters measured include intensity, current, and voltage. While power is the current and voltage values, efficiency is the ratio between the input and output values. The value of the test results shows the maximum voltage value is $0.020 \mathrm{~V}$, the current is $1.800 \mathrm{~A}$, power is $0.036 \mathrm{~W} / \mathrm{m}^{2}$, and efficiency is $0.007 \%$.
\end{abstract}

Keywords: DSSC, Exergy, Power, Efficiency, Arduino

\section{Introduction}

Solar energy is an energy source that is most widely used as a renewable energy source using photovoltaic. Photovoltaics can directly convert solar energy into environmentally friendly electrical energy [1]. The use of photovoltaic in every sector of needs continues to increase and triggers research to be able to produce good efficiency [2]. The current third-generation photovoltaic is Dye-Sensitized Solar Cell (DSCC) which is being developed by all researchers in the world [3].

DSSC is a type of solar cell that can be made easily and has a low production cost. The main component of this type of solar cell is an absorbent medium derived from titanium oxidants and natural dyes. These natural dyes can be found in trees, flowers, leaves, and fruit of plants that have anthocyanin substances and strong colour pigments [4-7]. The amount of electrical energy generated by the DSSC is strongly influenced by sunlight and the components of the DSSC, especially the absorbing layer and electron carrier. The better the process of absorption and electron flow, the better the current generated. DSSC performance can be seen from the results of measuring the intensity, temperature, current, voltage, power, and the resulting efficiency [8]. The process of measuring these parameters requires good measuring tools and in accordance with measurement standards. However, some measuring instruments available in the market have a fairly expensive price. Alternative measurements of solar cells using Arduino have been widely carried out [9-12], Measurement results are presented in the form of graphs and tables in real-time.

\section{Research methods}

The measurement process begins with assembling every component and sensor needed, after that filling in the input data and syntax on the Arduino software. The DSSC which is set perpendicular to the light source is connected to the measuring instrument that has been made. The measurement data display is connected to a laptop to present the data in real-time. The DSSC sample measurement process is only taken as much as 700 seconds. The DSSC measurement circuit is shown in Figure 1 which consists of a Computer, Arduino Nano, Temperature Sensor (LM35), Light Intensity Sensor (BH1750), Voltage Sensor, Current Sensor (ACS172), and a connecting cable.

\subsection{DSSC with Red fruit Absorbing}

Figure 2 shows the results of DSSC fabrication from red fruit with a size of $2.5 \times 2.5 \mathrm{~cm}$. The fabrication process is carried out using a simple pipette method, while the parts consist of: Glass Substrate, Transparent conducting layer $\left(\mathrm{TiO}_{2}\right)$, Organic Dyes, Electrolyte, Counter Electrode, and dye from red fruit. The working principle of DDSC starts from the arrival of photon energy on the cell surface from sunlight, this photon

\footnotetext{
* Corresponding author :hariyanto_ft@unmus.ac.id
} 
energy has different energy levels and then penetrates into the dye. Dye molecules that get energy are then excited to become electrons that flow through $\mathrm{TiO}_{2}$ and are oxidized again, capturing electrons from redox electrolyte ions and then generating electricity.

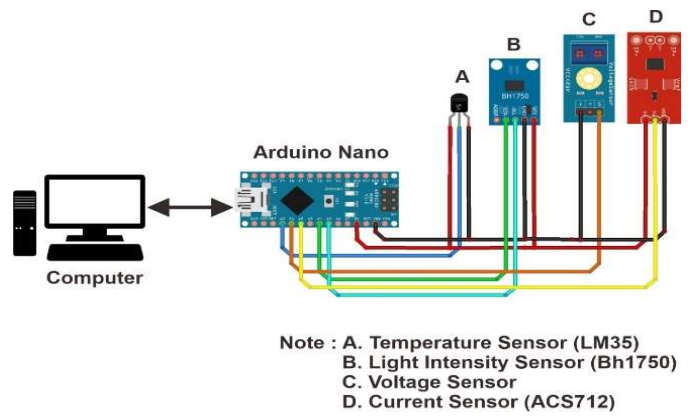

Fig. 1. Circuit Schematic.

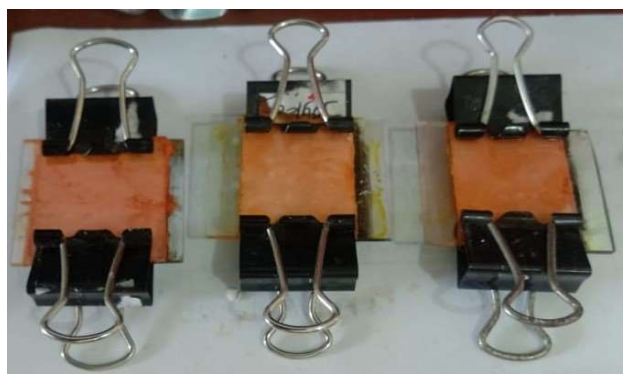

Fig. 2. Fabrication DSSC From Red fruit.

\subsection{Arduino Nano}

Arduino is an open-source physical computing platform. Arduino is not just a development tool, it is a combination of advanced hardware, programming language, and Integrated Development Environment (IDE). IDE is software that plays a very important role in writing programs, compiling them into binary code, and uploading them to the microcontroller memory.

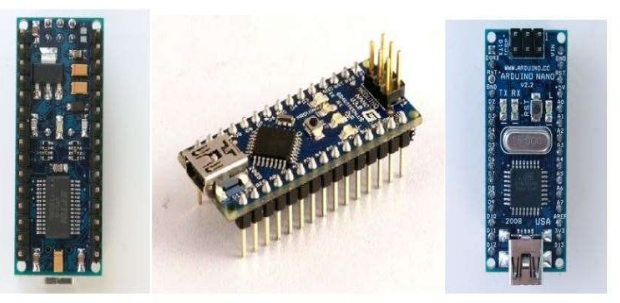

Fig. 3. Arduino Board

Arduino Nano is a microcontroller development board that is small, complete, and supports the use of breadboards. Arduino Nano is based on the ATmega328 (for Arduino Nano version 3.x) or ATmega 168 (for Arduino version 2.x) microcontrollers. The Arduino Nano has more or less the same functionality as the Arduino Duemilanove but in a different package. The Arduino Nano does not include a Barrel Jack-type DC plug and is connected to a computer using a Mini-B USB port. The Arduino Uno image is shown in Figure3.

\subsection{Intensity Sensor}

The intensity sensor used is the GY-302 BH1750 sensor type with an output of lux/meter, but the measurement results will be converted to $\mathrm{W} / \mathrm{m}^{2}$. This sensor serves to directly capture the intensity of the sun that arrives on the surface of the DSSC.

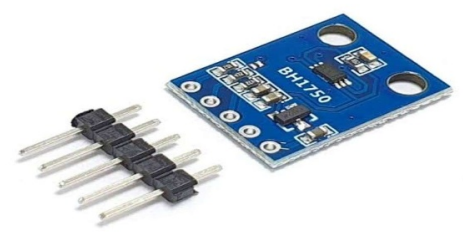

Fig. 4. Intensity Sensor GY-302 BH1750.

\subsection{Temperature Sensor}

The temperature sensor used is the LM35 sensor type. This sensor serves to measure the temperature level on 2 sides $\left(T_{1}\right.$ and $\left.T_{2}\right)$ of the DSSC, namely the lower side and the upper side.

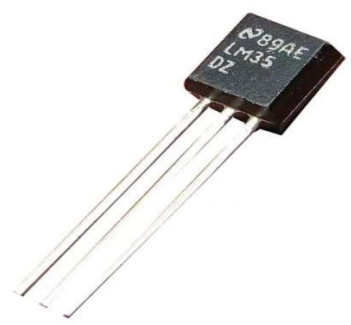

Fig. 5. Temperature Sensor LM35

\subsection{Current and Voltage Sensor}

Current and Voltage sensors are used to measure current and voltage in real-time. Figure 6 shows the ACS712 Current Sensor, while Figure 7. Shows the voltage sensor for Arduino.

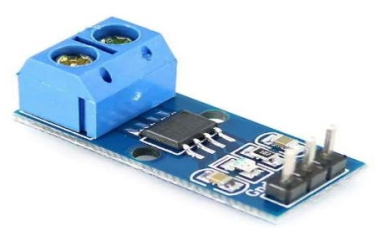

Fig. 6. Current Sensor ACS712

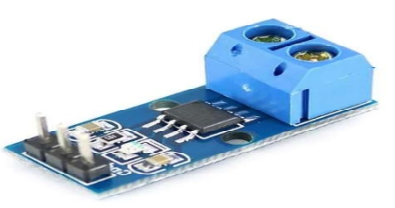

Fig. 7. Voltage Sensor 


\section{Results and Discussion}

\subsection{Result of Light Intensity}

The process of measuring the intensity value is carried out directly under the sun and parallel to the perpendicular. The intensity value displayed is the value of the intensity of sunlight which has been divided by the DSSC area, which is $2.50 \times 2.50 \mathrm{~cm}$.

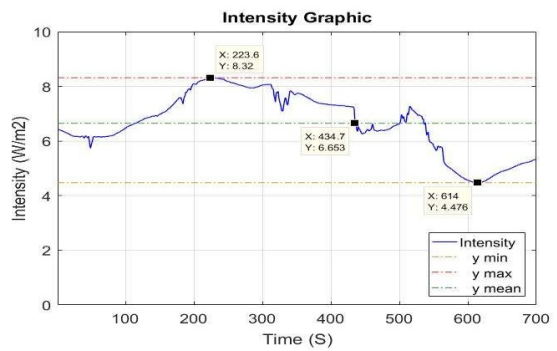

Fig. 8. Intensity Graphic

The intensity of sunlight hitting the surface of the DSSC greatly affects the value of the current generated $[13,14]$. The greater the intensity, the greater the number of photons involved in the conversion process, so the greater the current generated. The results of the intensity measurements in Figure 8 show the spectrum and area that have been formed. The maximum intensity value is at points $\mathrm{x}: 223.6 \mathrm{~S}$ and $\mathrm{y}: 8.32 \mathrm{~W} / \mathrm{m}^{2}$, while the average intensity value is at points $x: 434.7 \mathrm{~S}$ and $y: 8.32 \mathrm{~W} / \mathrm{m}^{2}$, and the minimum intensity value is at point $\mathrm{x}: 614 \mathrm{~S}$ and $\mathrm{y}: 4.476 \mathrm{~W} / \mathrm{m}^{2}$.

\subsection{Result of Current and Voltage}

Figure 9 shows the results of measuring current and voltage values with respect to time. The generated current is quite significant, while the voltage is constant. The maximum current value is at point $\mathrm{x}: 28.73 \mathrm{~S}$ and $\mathrm{y}$ : $1.8 \mathrm{~A}$, while the average current value is at point $\mathrm{x}$ : $237.7 \mathrm{~S}$ and $\mathrm{y}: 1.723 \mathrm{~A}$, and the minimum current value is at point $\mathrm{x}: 407.9 \mathrm{~S}$ and $\mathrm{y}: 1.65 \mathrm{~A}$. Based on the measurement results and the data that has been obtained, it can be seen that the voltage produced is quite good but the current produced is less than optimal. This is because the DSSC resistance is still very large, causing the electrons injected from the dye to experience resistance, so the number of electrons flowing is small.

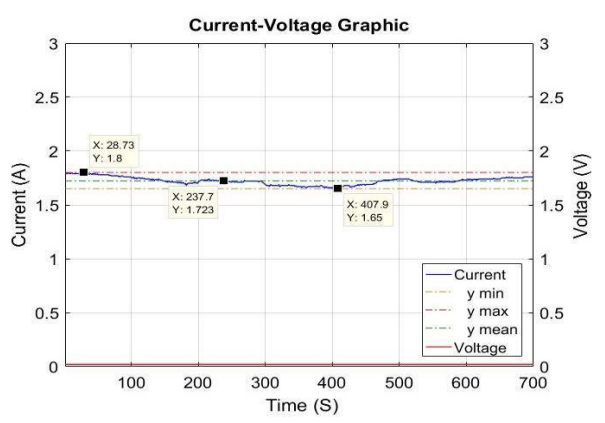

Fig. 9. Current and Voltage Graphic

\subsection{Result of Power and Efficiency}

Fig. 10. Power and Efficiency Graphic 1

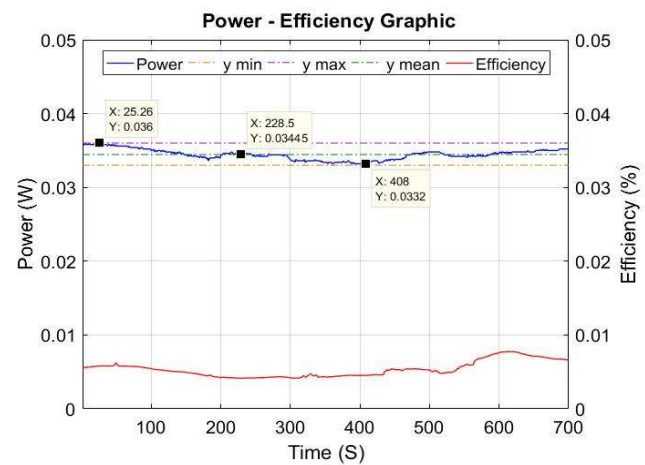

Output power and efficiency is an indicator of DSSC performance. Figure 10 shows the output power value against time. The measurement results show that the maximum power is at point $\mathrm{x}: 25.26 \mathrm{~S}$ and $\mathrm{y}: 0.036 \mathrm{~W}$, while the average power value is at point $\mathrm{x}: 228.5 \mathrm{~S}$ and $\mathrm{y}: 0.034 \mathrm{~W}$, and the minimum intensity value is at point $\mathrm{x}: 408 \mathrm{~S}$ and $\mathrm{y}: 0.033 \mathrm{~W}$.

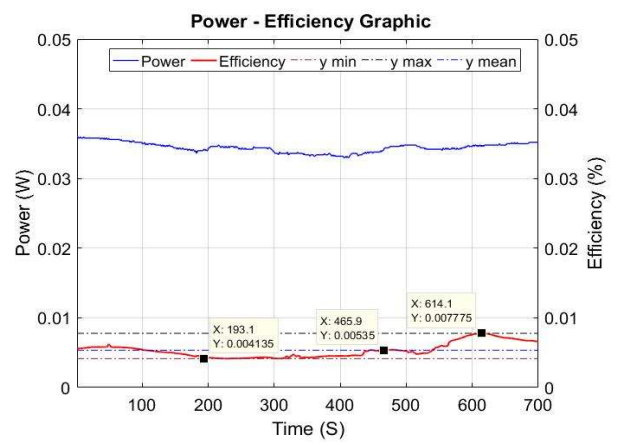

Fig.11. Power and Efficiency Graphic 1

Figure 11 shows the value of efficiency against time. The measurement results show that the maximum efficiency is at points $\mathrm{x}: 614.1 \mathrm{~S}$ and $\mathrm{y}: 0.0077 \%$, while the average efficiency value is at points $\mathrm{x}: 465.9 \mathrm{~S}$ and $\mathrm{y}: 0.0053 \%$, and the minimum efficiency value is at point $\mathrm{x}$ : $193.1 \mathrm{~S}$ and $\mathrm{y}$ : 0.0041\%.

Table 1. DSSC measurement result

\begin{tabular}{|c|c|c|c|}
\hline Parameter & $\begin{array}{c}\text { Maximum } \\
\text { Value }\end{array}$ & $\begin{array}{c}\text { Mean } \\
\text { Value }\end{array}$ & $\begin{array}{c}\text { Minimum } \\
\text { Value }\end{array}$ \\
\hline $\mathrm{G}\left(\mathrm{W} / \mathrm{m}^{2}\right)$ & 8.320 & 6.653 & 4.476 \\
\hline $\mathrm{T}_{1}\left({ }^{\circ} \mathrm{C}\right)$ & 32.5 & 32.5 & 32.5 \\
\hline $\mathrm{T}_{2}\left({ }^{\circ} \mathrm{C}\right)$ & 31 & 31 & 31 \\
\hline $\mathrm{V}($ Volt $)$ & 0.020 & 0.020 & 0.020 \\
\hline $\mathrm{I}$ (Ampere) & 1.800 & 1.723 & 1.650 \\
\hline $\mathrm{P}$ (Watt) & 0.036 & 0.034 & 0.033 \\
\hline $\begin{array}{c}\text { Efficiency } \\
(\%)\end{array}$ & 0.007 & 0.005 & 0.004 \\
\hline
\end{tabular}

Table 1 shows the measurement data presented in detail. The values of Intensity, Current, Voltage, power, and efficiency fluctuate during measurement while the values of temperature and voltage are constant. These results indicate that the use of Arduino as a measuring tool is very effective and efficient. These values can 
already describe the characteristics and performance of the DSSC that has been made.

\section{Conclusion}

The results of the DSSC measurement and analysis using Arduino have good and effective results. All measurement data can be displayed in real-time. The value of the test results shows the maximum value of voltage is $0.020 \mathrm{~V}$, the current is $1.800 \mathrm{~A}$, power is 0.036 $\mathrm{W}$ and efficiency is $0.007 \%$. Based on the experimental results and the data obtained, the voltage generated is quite good, but the current produced is less than optimal. This is because the DSSC resistance is still very large, causing the electrons injected from the dye to experience resistance, so the number of electrons flowing is small. The intensity value greatly affects the output power of the DSSC. The greater the intensity, the more photons involved in the conversion process, so the greater the current generated.

\section{References}

1. P. G. V. Sampaio and M. O. A. González, Photovoltaic solar energy: Conceptual framework, Renew. Sustain. Energy Rev., vol. 74, no. June 2016, pp. 590-601, (2017), doi: 10.1016/j.rser.2017.02.081.

2. M. G. Sekhar, K. Upendra, P. Kamalakar, and T. Sanjeevarao, Solar Photovoltaic Technology for Industrial and Domestic Applications, vol. 1, no. 2, pp. 56-58, (2017).

3. V. Rondán-Gómez et al., Recent advances in dyesensitized solar cells, Appl. Phys. A Mater. Sci. Process., vol. 125, no. 12, pp. 6-8, (2019), doi: 10.1007/s00339-019-3116-5.

4. T. Fernando, Ridwan, and dkk, Dye Sensitized Solar Cells (DSSC) Berbasis Nanopori TiO 2 Menggunakan Antosianin dari Berbagai Sumber Alami, Semirata FMIPA Univ. Lampung, pp. 155162, (2013).

5. R. Damayanti, Hardeli, and H. Sanjaya, Preparasi Dye Sensitized Solar Cell (DSSC) Menggunakan Ekstrak Antosianin Ubi Jalar Ungu (Ipomea batatas L.), J. Sains dan Teknol., vol. 6, no. 2, pp. 148-157, (2014).

6. P. Trihutomo, S. Soeparman, D. Widhiyanuriyawan, and L. Yuliati, Performance Improvement of Dye-Sensitized Solar Cell- (DSSC) Based Natural Dyes by Clathrin Protein, mInt. J. Photoenergy, vol. 2019, pp. 1-9, (2019), doi: $10.1155 / 2019 / 4384728$.

7. N. Burhan and H. P. Uranus, Performance Degradation Model of Dye-Sensitized Solar Cell (DSSC) Using Dye Extracted from Red Dragon Fruit's Flesh, J. Phys. Conf. Ser., vol. 1552, no. 1, (2020), doi: 10.1088/1742-6596/1552/1/012001.

8. H. Hariyanto, N. Fergiansyah, M. Rusdi, and D. Parenden, Karakteristik Dye Sensitized Solar Cell
(DSSC) dari ekstrak sari buah merah (Pandanus Coneideus), vol. 03, no. 01, (2020).

9. A. Rezky, K. Devara, N. S. Wardana, S. Ramadhanty, and T. Abuzairi, Simple method for I$V$ characterization curve for low power solar cell using arduino nano, E3S Web Conf., vol. 67, pp. 15, (2018), doi: 10.1051/e3sconf/20186701020.

10. J. Asmi and O. Candra, Prototype Solar Tracker Dua Sumbu Berbasis Microcontroller Arduino Nano dengan Sensor LDR, JTEV (Jurnal Tek. Elektro dan Vokasional), vol. 6, no. 2, p. 54, (2020), doi: 10.24036/jtev. v6i2.108504.

11. F. I. Pasaribu and M. Reza, Rancang Bangun Charging Station Berbasis Arduino Menggunakan Solar Cell $50 \mathrm{WP}$, R E L E (Rekayasa Elektr. dan Energi) J. Tek. Elektro, vol. 3, no. 2, pp. 46-55, (2021).

12. A. Aslam et al., Dye-sensitized solar cells (DSSCs) as a potential photovoltaic technology for the selfpowered internet of things (IoTs) applications, Sol. Energy, vol. 207, no. June, pp. 874-892, (2020), doi: 10.1016/j.solener.2020.07.029.

13. H. Hariyanto, M. Mustofa, Z. Djafar, and W. H. Piarah, Mathematical Modeling in Combining Photovoltaic and Thermoelectric Generator using a Spectrum Splitter, EPI Int. J. Eng., vol. 2, no. 1, pp. 74-79, (2019), doi: 10.25042/epiije.022019.13.

14. D. Parenden and Hariyanto, Simulation of photovoltaic concentration with Fresnel lens using Simulink MATLAB, Eur. J. Electr. Eng., vol. 21, no. 2, pp. 223-227, (2019), doi: 10.18280/ejee.210214. 